\title{
NON-LINEAR PRICE TRANSMISSION BETWEEN BIOFUELS, FUELS AND FOOD COMMODITIES
}

\author{
Ladislav Kristoufek \\ Karel Janda \\ David Zilberman
}

Cha res University

Centerfor Economic Research and Graduate Education

Academy of Sciences of the Czech Republic

Ec onomics Institute

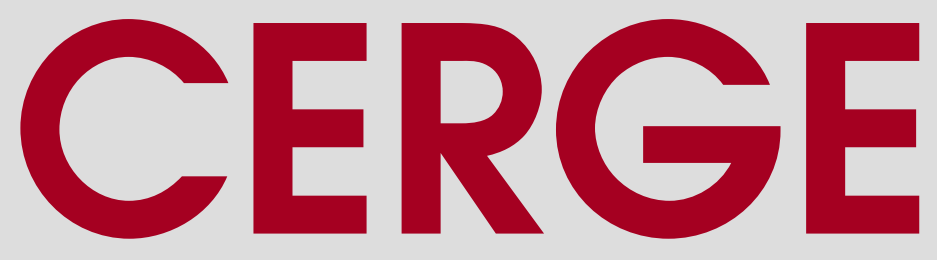




\title{
Working Paper Series $\quad 481$ (ISSN 1211-3298)
}

\section{Non-linear Price Transmission between Biofuels, Fuels and Food Commodities}

\author{
Ladislav Kristoufek
}

Karel Janda

David Zilberman

CERGE-EI

Prague, February 2013 
ISBN 978-80-7343-285-0 (Univerzita Karlova. Centrum pro ekonomický výzkum a doktorské studium)

ISBN 978-80-7344-277-4 (Národohospodářský ústav AV ČR, v.v.i.) 


\title{
Non-linear Price Transmission between Biofuels, Fuels and Food Commodities *
}

\author{
Ladislav Kristoufek ${ }^{\dagger}$ Karel Janda ${ }^{\ddagger}$ David Zilberman ${ }^{\S}$
}

\author{
February 2013
}

\begin{abstract}
For the biofuel markets and related commodities, we study their price transmission, which is in fact equivalent to studying price cross-elasticities. Importantly, we focus on the price dependence of the price transmission mechanism. Several methodological caveats are discussed. Specifically, we combine the memory robust feasible generalized least squares estimation with two-stage least squares to control for endogeneity bias and inconsistency. We find that both ethanol and biodiesel prices are responsive to their production factors (ethanol to corn, and biodiesel to German diesel). The strength of transmission between both significant pairs increased remarkably during the food crisis of $2007 / 2008$. Causality tests further show that price changes in production factors lead the changes in biofuels even after controlling for price effects.

\section{Abstrakt}

V této práci se zabýváme cenovým přenosem na trhu biopaliv a s nimi provázaných komodit. Analýza cenového přenosu odpovídá analýze cenových kř́žových pružností. Zaměřujeme se na závislost mechanismu cenového přenosu na úrovni cen. Diskutujeme několik metodologických problémů. Propojujeme metodu zobecněných a dvoustupňových nejmenších čtverců s cílem vzít v úvahu vychýlení a nekonzistenci odhadu způsobené endogenitou proměnných. V naší analýze zjištujeme, že ceny etanolu i bionafty reagují na své výrobní faktory (etanol na kukuřici, bionafta na německou naftu). Sila cenového přenosu mezi oběma významnými páry komodit výrazně vzrostla během potravinové krize v letech 2007/2008. Testování kauzality dále odhaluje, že změny cen výrobních faktorů vedou ke změnám cen biopaliv, i když bereme v úvahu cenové vlivy.
\end{abstract}

Keywords: biofuels, price transmission, price cross-elasticity, causality

JEL classification: C22, Q16, Q42

*Karel Janda acknowledges research support provided during his long-term visits at University of California, Berkeley and Australian National University. Our research was supported by the Energy Biosciences Institute at University of California, Berkely, the grants P402/11/0948 and 402/09/0965 of the Grant Agency of the Czech Republic, and by institutional support grant VSE IP100040. The views expressed here are those of the authors and not necessarily those of our institutions. All remaining errors are solely our responsibility.

†Institute of Economic Studies of the Faculty of Social Sciences of Charles University and Institute of Information Theory and Automation, Academy of Sciences of the Czech Republic. kristoufek@ies-prague.org.

${ }^{\ddagger}$ Institute of Economic Studies of the Faculty of Social Sciences of Charles University, University of Economics, Prague, and Affiliate Fellow at CERGE-EI. Correspondence address: IES FSV UK, Opletalova 26, 11000 Praha 1, Czech Republic, Karel-Janda@seznam.cz.

$\S$ University of California in Berkeley. zilber11@berkeley.edu. 


\section{Introduction}

The development of biofuels is key to tackling the interrelated problems of climate change and food and energy security. Early economic research of biofuels (Rajagopal and Zilberman, 2007) was very much concerned with engineering-like calculations of transformation ratios among basic food commodities used for the production of biofuels, with energy and greenhouse gas emission comparisons between biofuels and fossil fuels, and with the evaluation of economic effects of biofuel mandates and subsidies. The most important economic research questions related to the current development of biofuels are far more concerned with their price characteristics and cross-relationships as basic building blocks for the economic modeling of indirect land use changes related to biofuel production and consumption (Janda et al., 2012; Serra and Zilberman, 2012).

Price linkages between the food, energy and biofuel markets have therefore become one of the most discussed topics for energy, environmental and agricultural economists interested in the question of sustainable development of biofuels (Timilsina et al., 2011; Langholtz et al., 2012; Zilberman et al., 2012; Kristoufek et al., 2012a). A unique feature of our paper is that we consider price transmission in both major biofuel production lines and over the whole biofuel production cycle. This is a major step forward as compared with the literature which deals only with crude oil and agricultural commodities (Cha and Bae, 2011; Ciaian and Kancs, 2011a,b; Nazlioglu, 2011; Nazlioglu and Soytas, 2011, 2012), only with fossil fuels and biofuels (Pokrivcak and Rajcaniova, 2011; Rajcaniova et al., 2011), only with biofuels and agricultural feedstock (Carter et al., 2012) or only with one type of biofuel (Thompson et al., 2009; Du et al., 2011). It is especially common that fossil fuels (gasoline or diesel) are not directly included in the analysis (Serra et al., 2010). A further advantage is that our paper is not restricted to one particular country like the US, which receives major attention in the biofuel time-series literature.

We first analyze price transmission between the prices of the two most-used biofuels (ethanol and biodiesel), related feedstock, and fossil fuels. Further, we examine 
whether increases in biofuel prices cause the prices of agricultural commodities to rise as well, or vice versa. Moreover, a focus is put on potential price dependencies of the transmission mechanism, i.e. whether the connections and effects between specific pairs of commodities change with the price level of one of them.

An important novelty of our approach lies in its methodology as well. We show that the prices of ethanol and biodiesel are strongly trending in time and are seasonal. After controlling for these effects, the series neither contain a unit root nor are fractionally integrated, implying that neither cointegration nor fractional cointegration should be used for their analysis as is frequently done in the literature (see e.g. (Zhang et al., 2009, 2010; Serra et al., 2011; Pokrivcak and Rajcaniova, 2011)). Obviously these studies used a different data set than our paper. Our empirical results therefore do not imply that these studies were wrong, but they emphasize the need for checking the validity of assumptions allowing the use of cointegration techniques after controlling for time trends and seasonality. As the series remain weakly dependent, we apply Prais-Winsten methodology to control for such dependence. Moreover, the biofuel system is suspected to include at least several endogenous variables. To control for this, we apply a combination of PraisWinsten methodology and two-stage least squares approach. Such an approach is very novel in the biofuels-related literature. In causality testing, we again focus on a methodological issue which is not usually dealt with in the literature - stationarity. Even though stationarity is standardly tested in Granger-type causality tests, an assumption of heteroskedasticity is frequently omitted (see e.g. (McPhail, 2011; Ciaian and Kancs, 2011b; Pokrivcak and Rajcaniova, 2011)).

Controlling for all the mentioned effects, we find that ethanol is significantly connected to corn and crude oil, while biodiesel is mainly connected to German diesel. Other transmission effects are either economically or statistically insignificant. We also find that the significant price transmission is price-dependent. The price dependence is most visible for the ethanol-corn pair - it is close to zero for average prices of corn but can climb up to almost unity for high historical prices. 
As the price of commodities evolves over time, we are able to transform the pricedependent transmission effects into time-dependent ones. By doing so, we show that the price transmission mechanism between the analyzed commodities varies over time while the most interesting dynamics were observed for the year 2008, which is considered the year of the global food crisis.

The causality tests reveal that an increase in corn prices causes an increase in ethanol prices in the short term. For biodiesel, we find a causal relationship from German diesel to biodiesel, which is again positive in both the short and medium term. When the possible price effect on causality is taken into consideration, the found relationships are supported. The analyzed biofuels are thus influenced by their producing factors and not vice versa.

Our paper is solely concerned with price analysis. This is consistent with a large literature which aims to understand linkages between the prices of different fuels. But prices are the outcome of a system that includes factors of quantity, supply and demand, etc. Therefore, prices are affected by all of these variables and to some extent they provide an understanding of how different related markets operate. This is very important for the construction of economic models of indirect land use change (Khanna et al., 2011; Chen et al., 2012) caused by biofuels. As opposed to early models of direct land use changes, which were typically based on energy and biology related transformation processes, indirect land use change (ILUC) is a complex process driven by the economic (price) effects on demand and supply and as such may be estimated only through economic models.

Our results suggest that economic models of ILUC should not assume constant cross-price elasticities (price transmissions) and price-level independent causality relationships among various elements of the biofuel production and consumption cycle. We also confirm that ILUC models should take into account the dynamics of the transmission mechanism and causalities related to extreme price changes during food crises. More generally, our price- and time-dependent price transmissions and causalities are very appropriate for modeling the effects of biofuels in the era of gen- 
eral commodity price increase, commonly reflected since the start of the $2007 / 2008$ food crisis, as opposed to the long period of relative commodity price stability which was characteristic of the earlier period.

The paper is organized as follows. In Section 2, we describe our methodology in some detail. Section 3 contains a detailed description of the data set as well as comments on its trending and seasonality. In Section 4, we present the results for the price transmission mechanism as well as causality tests. Section 5 concludes.

\section{Methodology}

\subsection{Theoretical framework}

The biofuel market can be treated as a standard economic market with a marketclearing price determined by a supply and a demand for the commodity. In a partial equilibrium framework based on Serra et al. (2010), the basic characteristics of the biofuel markets - technological and regulation constraints - are included. In the standard equilibrium without constraints, biofuel prices are set at the intersection $E$ of the biofuel demand curve $D\left(P_{B}, P_{G}\right)$ and the biofuel supply curve $S\left(P_{B}, P_{F}\right)$ in Fig. 1, where $P_{B}, P_{F}, P_{G}$ are the prices of relevant biofuel, its feedstock and an appropriate fossil fuel, respectively. The price of biofuel increases with a demand curve shift caused by the increasing price of the relevant fossil fuel, eventually reaching a new equilibrium level $E_{1}$ with a higher price and quantity. A supply curve shifts with an increasing feedstock price leading to a new equilibrium $E_{2}$ with a higher price and a lower quantity. This simple unrestricted equilibrium analysis implies that at least in the long term, the movements in prices of biofuels, fossil fuels and feedstock are strongly positively correlated and the changes in biofuel prices are caused by the behavior of the feedstock and fossil fuels.

However, important drivers of biofuel development are regulatory supports like mandates, blending obligations, subsidies, etc. (Chen et al., 2011; Khanna et al., 2008) and technological feasibility (production capacities and technological possi- 


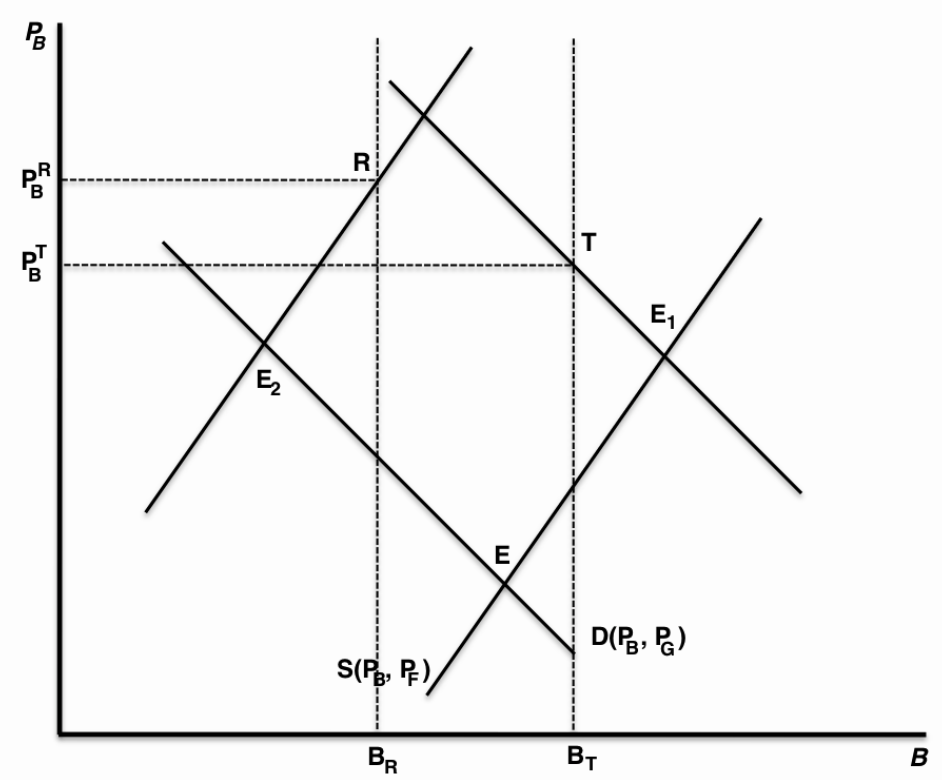

Figure 1: Determination of the Price of Biofuel

bilities of biofuel utilization). Accounting for this, the description of supply and demand in Fig. 1 includes regulatory and technological constraints denoted by vertical straight lines through points $B_{R}$ and $B_{T}$, respectively. Taking these constraints into account, we obtain minimum and maximum possible quantity of a specific biofuel on the market. Therefore, equilibria $E_{1}$ and $E_{2}$ are no longer attainable. Resulting non-equilibrium market situations $T$ or $R$ are associated with biofuel prices $P_{B}^{T}$ or $P_{B}^{R}$, respectively, which are higher than for the equilibria situations $E_{1}$ and $E_{2}$.

In effect, the technological and regulatory constraints influence the shape of the supply and demand curve, respectively. The demand curve is a vertical line overlapping with the line of the constraint down to the intersection with the unrestricted demand curve and then behaves just as a standard decreasing demand function. In a similar way, the supply curve is increasing with quantity up to the intersection with the technological constraint where it becomes a vertical. When the constraints are taken as fixed, both the demand and supply functions change their shape when the prices of relevant fossil fuels or feedstock, respectively, increase or decrease, i.e. they are not just shifted one way or another. Moreover, we can consider the constraints as being variable (either in time, or for individual market agents so that 
they change on an aggregate level) or not precisely definable. This may lead to demand and supply functions which are not just broken-linear functions but nonlinear functions converging to the constraint. One way or another, there is a strong possibility that the demand and supply functions are not linear and are likely to change their shape, which leads to possibly price-dependent links and co-movements between commodities. This non-linear time-evolving dynamics of biofuel prices is investigated in our paper. In our econometric model we explicitly control for prices $P_{F}, P_{G}$ while assuming that efficiently functioning commodity markets incorporate into the prices $P_{B}, P_{F}, P_{G}$ the institutional features of biofuel markets like mandates and blending walls which we introduced in Fig. 1.

An important novel feature of our paper is a consideration of the whole biofuel related production cycle as opposed to most of the literature which looks only at a small number of related markets. For example only ethanol, sugar, gasoline and oil or ethanol, corn, gasoline, oil are considered in even the broadest and most inclusive papers in the literature (for recent reviews of biofuel-related price transmission models see Janda et al. (2012); Serra and Zilberman (2012)). Generally, the literature may have some locational emphasis (i.e. considering Brazilian ethanol when looking at sugarcane and US ethanol when looking at corn) but the real underlying assumption is that the global markets are considered implicitly. Yet, in reality, our results suggest that by using data on more markets (US and German markets in our case), we may identify linkages at the commodity level, linkages at the input level, and most importantly, linkages due to time and space. Namely, it is not only substitution in the final use that matters, but where production occurs and the related substitution of use of inputs among activities. Furthermore, the time and cost of moving commodities across locations really matters. This is why we find a strong correlation between European and American prices and a low correlation across the world. Even though modern economics speaks about globalized modern markets, there are transaction costs that cause location to matter and affect prices. Location does not only mean distances: different locations may have different regu- 
lations and these result in different patterns of price linkages between biofuel, fossil fuel and agricultural commodities. Furthermore, another important element is that time-different data tell a different story, and in the long run, relationships between markets are stronger than in the short run.

\subsection{Price transmission}

Econometric estimation of an elasticity is often based on an approximation in a $\log -\log$ specification of a linear regression. When we have variables $X$ and $Y$ and we estimate the model

$$
\log Y=\alpha+\beta \log X+\varepsilon,
$$

parameter $\beta$ is then taken as an approximation to elasticity as $\beta=\frac{\Delta Y / Y}{\Delta X / X}$ which is the definition of the elasticity of $Y$ with respect to $X$. In microeconomic demand analysis (Luchansky and Monks, 2009; Meyer et al., 2012), we usually deal with the elasticity of a demanded quantity with respect to a price, $e_{p}^{d}=\frac{\Delta Q_{d} / Q_{d}}{\Delta P / P}$. To analyze whether the relevant pair of goods is a pair of substitutes or complements, we are interested in cross-price elasticities of demand, $e_{p_{i}}^{d_{j}}=\frac{\Delta Q_{d_{j}} / Q_{d_{j}}}{\Delta P_{i} / P_{i}}$. In cases when we have no information about demanded quantities, we might be interested in price elasticities $e_{p_{i}}^{p_{j}}$ defined as $e_{p_{i}}^{p_{j}}=\frac{\Delta P_{j} / P_{j}}{\Delta P_{i} / P_{i}}$. To avoid confusion, we call this elasticity a price transmission between assets $i$ and $j$. This price transmission specifies how the price of a good $j$ reacts to the change in the price of a good $i$. It can be easily shown (Kristoufek et al., 2012b) that the price transmission parameter is actually a ratio between own-price elasticity of demand and cross-price elasticity of demand for a good $j$. In words, if $e_{p_{i}}^{p_{j}}>1$, i.e. the price of a good $i$ reacts more than proportionally to a change in the price of a good $j$, then the demanded quantity $Q_{d_{i}}$ is more sensitive to changes in $P_{i}$ than in $P_{j}$.

In the standard framework, all mentioned elasticities are assumed to be constant for all price levels. However, constant elasticities are a strong simplification. Returning to Fig. 1, there is no such restriction on the effect of $P_{F}$ and $P_{G}$ on $P_{B}$. The 
effect of $P_{F}$ on the supply $S\left(P_{B}, P_{F}\right)$ and the effect of $P_{G}$ on the demand $D\left(P_{B}, P_{G}\right)$ may take various forms. The expectations are that the price transmission effect between $P_{F}$ and $P_{F}$ is increasing in prices. This might reflect the situation in which the substitution effect between fossil fuels and biofuels is low when the prices of fossil fuels are low as well as the effect of increasing costs which is low when the prices of feedstock are low (and are likely to be offset by subsidies). To analyze such a price dependence of the transmission mechanism, we need to generalize the expression of the elasticity from the original log-log regression in Eq. 1. To obtain the price dependence, we aim to arrive at

$$
e_{X}^{Y}=\beta+\gamma X+\delta X^{2}
$$

which captures price dependence to the second-order polynomial (the second-order polynomial is arbitrary here and can be easily generalized to higher orders). This form of the price transmission leads to the following model:

$$
\log Y=\alpha+\beta \log X+\gamma X+\frac{\delta}{2} X^{2}+\varepsilon
$$

The introduced concept of price transmission has an additional advantage over standard constant elasticities in its ability to control for price and, mainly, time dependence. Analyzing the transmission thus enables us to comment on the evolution of the relationship between two price series in time and its connection to relevant events on the corresponding markets. Obviously, the proposed methodology is not restricted only to biofuel markets, as we use it, but can be used on any portfolio of assets. In most cases, we expect that the absolute value of the price transmission effect is lower than one, i.e. that the price of $i$ reacts more to the changes in demanded quantity of asset $i$ than of asset $j$. However, it might happen that an asset reacts more to the changes of demanded quantity of the other asset, which could be associated with over reaction of market participants or explosiveness of the prices. Indeed, we find that for biofuel markets, the absolute value of the transmission 
effects remains below unity and there is not a single period where it is higher than unity on a statistical basis.

To obtain the price transmission effect for ethanol and biodiesel with respect to other commodities, we need to construct models according to Eq. 3 and include the variables of interest in set $X$. Since we are analyzing time series of the logarithmic prices, we need to carefully check the assumptions of OLS estimation as well as stationarity and possible trending and/or seasonalities. Especially for the time series, the assumption of no auto-correlation in the residuals is crucial. If we find that the auto-correlation in residuals is strongly significant and the detrended/deseasonalized explanatory variables are strongly auto-correlated as well (yet both remain far from a unit-root), OLS becomes inefficient (Wooldridge, 2009). In such a case, we need to switch to feasible GLS (FGLS) estimation - either Cochrane-Orcutt (Cochrane and Orcutt, 1949) or Prais-Winsten (Prais and Winsten, 1954) estimation. Both methods are based on quasi-differencing of the original series (see Kristoufek et al. (2012b) for details). We will stick to the Prais-Winsten version as it is more efficient for finite samples. Moreover, the analyzed biofuel system contains variables which are highly interconnected and affected by one another. Therefore, some of the variables might be endogenous, causing the estimates to be inefficient. To control for this, we also apply the two-stage least squares (2SLS) procedure.

To summarize the applied procedures and possibilities of estimation: if the series are stationary after detrending and the residuals of the estimated models are not highly autocorrelated, we apply standard OLS; if the residuals are autocorrelated and the variables are not endogenous, we utilize FGLS; if the residuals are autocorrelated and some variables are endogenous, we apply 2SLS combined with FGLS to obtain consistent estimates. Eventually, we apply the last procedure and the results are presented in Section 4, which distinguishes our work from other studies analyzing the price transmission between biofuels and related commodities. 


\subsection{Causality}

Even though transmission and elasticity give us some basic information about the relationship between two series, we cannot say anything about causality (Dahl, 2012). For the specific case of biofuel markets and related economic policies, the question of causality is probably more important that the price transmission itself.

If changes in the prices of a biofuel cause changes in the prices of the related feedstock, then it can be interpreted as that the increasing price of the biofuel offers profitable opportunities and more entrepreneurs will transfer into the biofuel market. This increases demand for the feedstock resulting in its increasing price, which might have some considerable social and environmental effects (e.g. higher prices of food, and feedstock field expansion). Conversely, if changes in feedstock prices are reflected in the changes of biofuel prices, it simply implies that the increased costs of feedstock production were transmitted into the biofuel prices.

When we turn to the relationship between biofuels and related fossil fuels, the causality is less clear. If the price change of the fossil fuel is transmitted to the price of biofuel, it might be caused by two factors. First, the increasing price of the fossil fuel motivates consumers to switch to using the biofuel, which increases the demand for biofuel and in effect its price. Second, as the actual biofuels used for powering motor vehicles are a mixture of the fossil fuel and only a fraction of the biofuel, these practically need to be correlated by construction. Causality from biofuel to the fossil fuel is quite unlikely but, if occurrent, can be attributed to an indirect effect from increasing feedstock prices, which push the biofuel prices higher resulting in higher demand for fossil fuels, i.e. higher prices.

To analyze the causality, we construct a Granger-like causality test (Granger, 1969), which is commonly used in a standard vector autoregression (VAR) framework. The test itself is very simple and is based on the following regression:

$$
y_{t}=\alpha+\sum_{i=1}^{p} \beta_{i} y_{t-i}+\sum_{j=1}^{p} \gamma_{j} x_{t-j}+\varepsilon_{t}
$$


The null hypothesis ' $x$ does not Granger-cause $y$ ' is tested with use of an F-statistic for the hypothesis $\gamma_{1}=\ldots=\gamma_{p}=0$. The lag order $p$ is chosen with respect to the structure of the data. The test presented in Eq. 4 has only one assumption and that is stationarity of both $x_{t}$ and $y_{t}$ for $t=1,2, \ldots, T$. To test stationarity, we will use standard ADF, ADF-GLS (Dickey and Fuller, 1979; Elliot et al., 1996) and KPSS (Kwiatkowski et al., 1992) tests. To control for heteroskedasticity, we use GARCH(1,1)-filtered series (Bollerslev, 1986) as homoskedasticity is also needed for stationarity and is not controlled for in ADF and KPSS tests. The need for GARCH-filtering is stressed more fully in the Results section.

\section{Data description and model specifications}

In this section, we carefully describe the dataset and follow with the model specification used for the estimation of the price transmission in the analyzed biofuel system.

\subsection{Dataset}

The main aim of this paper is to analyze the price transmission mechanism between biofuels, their related production factors, and related fossil fuels. Since our focus is on biodiesel and ethanol, we include only relevant agricultural commodities which are used for their production, and only relevant fossil fuels, which are their respective natural substitutes. Our dataset thus contains consumer biodiesel $(B D)$, ethanol $(E)$, corn $(C)$, wheat $(W)$, soybeans $(S)$, sugarcane $(S C)$, crude oil $(C O)$, German diesel $(G D)$ and US gasoline $(U S G)$. Corn, wheat and sugarcane are the feedstock for ethanol; soybeans are the feedstock for biodiesel. As ethanol is mainly the US domain and its natural substitute is gasoline, we include US gasoline. In a similar way, biodiesel is predominantly the EU domain and its substitute is diesel, thence German (as the biggest EU economy) diesel is included. Crude oil (Brent) is included as well because it serves as a production factor for all fuels in our dataset, 
at least indirectly. A majority of the dataset was obtained from the Bloomberg database (Table 1): the two fossil fuels were obtained from the US Energy Information Administration and include the countries' average price. As the price series of the biofuels are very illiquid, we analyze weekly data for the period between 24.11.2003 and 28.2.2011 (Monday closing prices).

Table 1: Analyzed Bloomberg Commodities

\begin{tabular}{c|c|c}
\hline \hline Commodity & Ticker & Contract type \\
\hline \hline Crude oil & CO1 Comdty & $1^{\text {st }}$ month futures, ICE \\
Ethanol & ETHNNYPR Index & Spot, FOB \\
Corn & C 1 Comdty & $1^{s t}$ month futures, CBOT \\
Wheat & W 1 Comdty & $1^{s t}$ month futures, CBOT \\
Sugarcane & SB1 Comdty & $1^{s t}$ month futures, ICE \\
Soybeans & S 1 Comdty & $1^{s t}$ month futures, CBOT \\
Biodiesel & BIOCEUGE Index & Spot, Germany \\
\hline
\end{tabular}
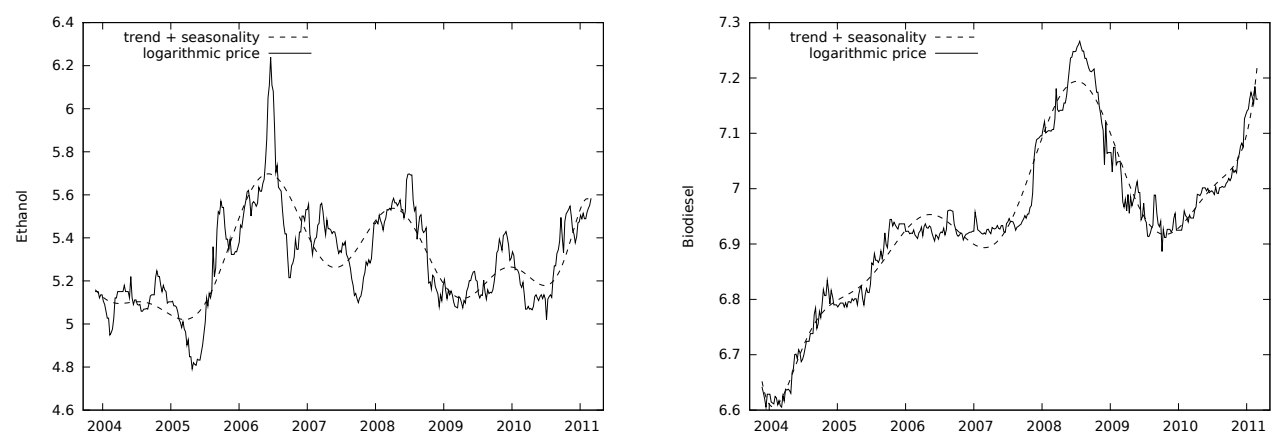

Figure 2: Logarithmic Prices of Ethanol (Left) and Biodiesel (Right) with Corresponding Time Trends and Seasonal Effects

Logarithmic prices of the biofuels of interest - ethanol and biodiesel - are shown in Fig. 2. In the charts, we also present the fitted values based on time trend and seasonality. Since weekly data are analyzed, we can work with fact that a year has 52 weeks, which in turn enables us to include various seasonalities (cycles) into the time-trend filtering. We pick an 8-year cycle as the longest (one year longer than the actual length of the dataset due to evenness) and the shortest cycle is taken as 13 weeks, i.e. a quarter of a year. The filtering model looks as follows

$$
\log B F_{t}=\alpha+\sum_{i=1}^{4} \beta_{i} t^{i}+\sum_{j=1}^{2} \gamma_{j} \sin \left(\frac{2 \pi t}{13 j}\right)+\sum_{k=1}^{8} \delta_{k} \sin \left(\frac{2 \pi t}{52 k}\right)+\varepsilon_{t}
$$


where $\log B F_{t}$ is the logarithmic price of the biofuel in time $t$. The insignificant trend and seasonal variables were omitted to arrive at more efficient estimates and thus more accurate fitted values. Nevertheless, it is clearly visible that both the time trend and seasonality effects are significant for both biofuels. Therefore, these time and seasonal variables should be included in the final regression estimating the price transmission. Such a procedure is important for correct selection of an appropriate modeling procedure since we need to separate the potential unit roots from the time trend and seasonality effects. If a unit root is found in the variable of interest, it leads to either cointegration techniques (and vector error-correction models) or vector autoregression (VAR) models with differenced series. Therefore, testing for stationarity and unit roots becomes crucial (note that we are predominantly interested in showing that the specific series is or is not unit root so homoskedasticity is not important in this case). The results for ADF (Dickey and Fuller, 1979), ADF-GLS (Elliot et al., 1996) and KPSS (Kwiatkowski et al., 1992) are summarized in Table 2. The results are straightforward - unit root is not rejected for the original series but is strongly rejected when the series are appropriately detrended and deseasonalized. Even though the detrended series are strongly autocorrelated (the sample first-order autocorrelations are 0.9218 and 0.8354 for ethanol and biodiesel, respectively), they do not contain a unit root. Standard cointegration and VAR with differences methods cannot therefore be used. Note that detrending and seasonality effects are usually not taken into consideration in the relevant literature, which raises serious questions about correctness of the results and following implications. Therefore, we can proceed with standard least squares estimation. If OLS estimation is found inefficient and inconsistent, which is the case for strongly dependent residuals, we will switch to Prais-Winsten regression. If the estimated models do not pass the Hausman specification test (Hausman, 1978), we apply the 2SLS estimation to additionally control for endogenity. The procedure is thus robust to both strong memory in the disturbances and to endogenous variables. Note that such an approach is applied for the first time to the biofuel system. 
Table 2: Unit-root and Stationarity Tests. Note: the null hypotheses are: "a unit root series" for ADF and ADF-GLS, "stationary series" for KPSS)

\begin{tabular}{c|cc|cc|cc}
\hline \hline Series & ADF & p-value & ADF-GLS & p-value & KPSS & p-value \\
\hline \hline Ethanol log-prices & -2.3265 & $>0.1$ & -1.8437 & 0.0622 & 1.9377 & 0.0000 \\
Biodiesel log-prices & -1.5075 & $>0.1$ & 0.9759 & $>0.1$ & 11.2302 & 0.0000 \\
\hline Ethanol detrended & -4.4399 & 0.0001 & -4.4390 & 0.0000 & 0.0653 & $>0.1$ \\
Biodiesel detrended & -4.5714 & 0.0001 & -4.3329 & 0.0000 & 0.0961 & $>0.1$ \\
\hline
\end{tabular}

\subsection{Model specification}

As we have shown in the previous section, both the time trend and seasonal effects are significant in the dynamics of the logarithmic prices of ethanol and biodiesel. Therefore, these need to be included in the final model. The general form of the model estimating the price-dependent mutual responsiveness while controlling for time and seasonal effects is

$$
\begin{array}{r}
\log B F_{t}=\alpha+\sum_{i=1}^{4} \beta_{i} t^{i}+\sum_{j=1}^{2} \gamma_{j} \sin \left(\frac{2 \pi t}{13 j}\right)+\sum_{k=1}^{8} \delta_{k} \sin \left(\frac{2 \pi t}{52 k}\right)+\sum_{l=1}^{I} \xi_{l} \log P_{l}+ \\
\sum_{m=1}^{I} \phi_{m} P_{m}+\sum_{n=1}^{I} \nu_{n} P_{n}^{2}+\varepsilon_{t}
\end{array}
$$

where $\log B F_{t}$ is the logarithmic price of either ethanol or biodiesel in time $t$ and $I$ is the number of impulse variables. In the sums with parameters $\xi, \phi$ and $\nu$, the relevant impulse variables are included. Logarithmic, linear and quadratic forms should uncover potential price-dependent relationships between the specific biofuel and relevant commodities and/or other fuels. For ethanol, the set of impulse variables includes corn, wheat, sugarcane, soybeans, crude oil and US gasoline. And for biodiesel, we include corn, wheat, sugarcane, soybeans, crude oil and German diesel. We keep all agricultural commodities of the dataset in both models because we are mainly interested in the possible effect of biofuels on their prices (or vice versa). A single fossil fuel is kept in each regression to avoid collinearity problems as these are highly correlated. From a technological point of view, we expect corn, wheat, sugarcane and US gasoline to influence the dynamics of the ethanol prices, 
and only soybeans and German diesel to affect biodiesel.

\section{Results}

We present the results separately for price transmission and causality.

\subsection{Price transmission}

After running the OLS regression for ethanol price transmission, we arrived at the first-order autocorrelation coefficient of the residuals equal to 0.7609 with the Durbin-Watson statistic equal to 0.4758 . The residuals are thus highly positively autocorrelated as suspected, which leads us to more efficient FGLS methodologies. However, the Hausman test statistic comparing FGLS and 2SLS yields 50.99 with a $p$-value of 0.0236 , thus rejecting that FGLS estimation is consistent, and leading us to the 2SLS procedure. The estimates for the reduced ethanol model based on 2SLS-FGLS regression are summarized in Table 3. We first observe that the model includes only two impulse variables - corn and crude oil. Note that the final model explains the behavior of ethanol very well $\left(R^{2}=0.9574\right.$ for the quasi-differenced variables). The estimated price-dependent price transmission effects are shown in Fig. 3. Here, only corn shows interesting results. Note that the price of corn ranges approximately between $\$ 200$ and $\$ 700$. Therefore, most of the time, the elasticity between corn and ethanol is close to zero, and becomes both statistically and economically significant for high prices of corn and attains values up to 0.7. The price dependence of ethanol-crude oil transmission shows a linear dependence on the price of crude oil, but the confidence intervals remain very wide so that for all realistic values of the crude oil price, we remain very close to the zero price transmission.

The results for biodiesel are in general quite similar to those of ethanol. Most importantly, the OLS estimation procedure again yields highly autocorrelated residuals (with the first-order autocorrelation coefficient of residuals of 0.5664 and the 
Table 3: Reduced 2SLS-FGLS Model for Ethanol

\begin{tabular}{|c|c|c|c|c|c|}
\hline & \multicolumn{2}{|c|}{ Estimate } & $\mathrm{SE}$ & $t$-statistic & ic p-value \\
\hline const & \multicolumn{2}{|c|}{5.0167} & 0.1138 & 44.0982 & 0.0000 \\
\hline $\mathrm{CO}$ & \multicolumn{2}{|c|}{0.0021} & 0.0009 & 2.3927 & 0.0172 \\
\hline$C^{2}$ & \multicolumn{2}{|c|}{$4.47 * 10^{-7}$} & $1.68 * 10^{-7}$ & 2.3927 & 0.0083 \\
\hline period & & . & 25.9425 & 0.0002 \\
\hline time & \multicolumn{2}{|c|}{0.0030} & 0.0011 & 2.6385 & 0.0087 \\
\hline \multicolumn{2}{|l|}{$R^{2}$} & 0.957 & \multicolumn{2}{|c|}{ Adjusted $R^{2}$} & 0.9564 \\
\hline \multicolumn{2}{|c|}{$F(9,370)$} & 128.9732 & \multicolumn{2}{|c|}{$\mathrm{P}$-value $(F)$} & 0.0000 \\
\hline \multicolumn{2}{|c|}{$\hat{\rho}$} & 0.07 & Durbin & -Watson & 1.8453 \\
\hline
\end{tabular}
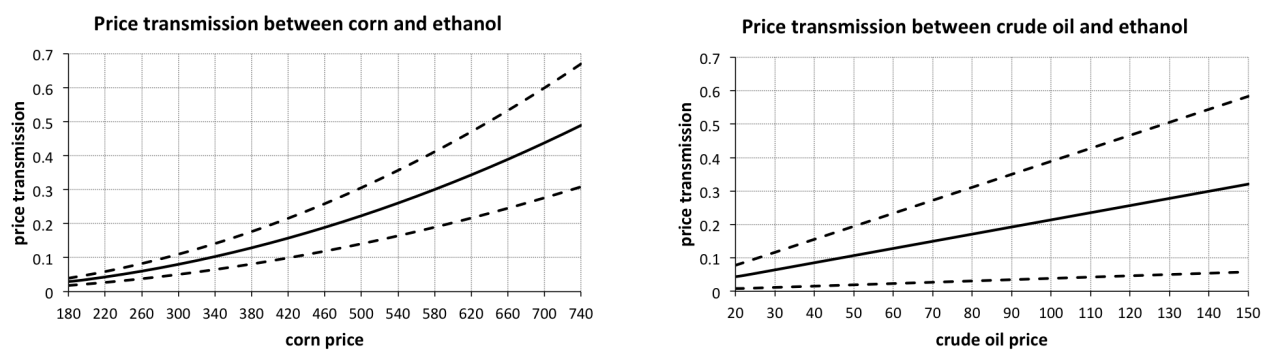

Figure 3: Price-dependent Mutual Responsiveness Between Ethanol and Corn (Left) and Crude Oil (Right)

Durbin-Watson statistic of 0.8693 ), which leads to Prais-Winsten regression. However, the Hausman specification test yields a test statistic of 948.79 which implies a $p$-value of practically zero, which again leads us to the 2SLS-FGLS estimation procedure. The reduced model (Table 4) gives us four statistically significant commodities - corn, wheat, soybeans and German diesel. In Fig. 4, we observe that the price transmissions of corn and soybeans with respect to biodiesel show the same behavior as for the crude oil-ethanol pair, i.e. the values of price transmission are statistically very close to zero for all feasible price levels. For wheat-biodiesel price transmission, we observe a non-zero effect only for very extreme prices of wheat. Therefore, the only statistically and economically significant price transmission effect is the biodiesel-German diesel pair. The effect is again price-dependent and reaches values around 0.3 for high prices of German diesel.

By obtaining the estimates of $\beta, \gamma$ and $\delta$, we are now able to comment on the time dependence of the price transmission between biofuels and related commodities. 
Table 4: Reduced 2SLS-FGLS Model for Biodiesel

\begin{tabular}{|c|c|c|c|c|c|c|c|}
\hline & \multicolumn{2}{|c|}{ Estimate } & \multicolumn{2}{|r|}{$\mathrm{SE}$} & \multicolumn{2}{|c|}{$t$-statistic } & p-value \\
\hline const & \multicolumn{2}{|c|}{5.1134} & \multicolumn{2}{|c|}{0.4530} & \multicolumn{2}{|c|}{11.2877} & 0.0000 \\
\hline$C$ & \multicolumn{2}{|c|}{0.0001} & \multicolumn{2}{|c|}{0.0001} & \multicolumn{2}{|c|}{2.4858} & 0.0134 \\
\hline$W$ & \multicolumn{2}{|c|}{-0.0013} & \multicolumn{2}{|c|}{0.0003} & \multicolumn{2}{|c|}{-4.4844} & 0.0000 \\
\hline$S$ & \multicolumn{2}{|c|}{0.0001} & \multicolumn{2}{|c|}{0.0000} & \multicolumn{2}{|c|}{-2.6291} & 0.0147 \\
\hline$G D$ & \multicolumn{2}{|c|}{0.0563} & \multicolumn{2}{|c|}{0.0083} & \multicolumn{2}{|c|}{6.7616} & 0.0000 \\
\hline $\log W$ & \multicolumn{2}{|c|}{0.3152} & \multicolumn{2}{|c|}{0.0909} & \multicolumn{2}{|c|}{3.4680} & 0.0006 \\
\hline$W^{2}$ & \multicolumn{2}{|c|}{$5.64 * 10^{-7}$} & \multicolumn{2}{|c|}{$1.23 * 10^{-7}$} & \multicolumn{2}{|c|}{4.5746} & 0.0000 \\
\hline time & \multicolumn{2}{|l|}{ - } & . & & \multicolumn{2}{|c|}{287.811} & 0.0000 \\
\hline perioc & \multicolumn{2}{|l|}{. } & . & & \multicolumn{2}{|c|}{216.405} & 0.0000 \\
\hline \multicolumn{2}{|c|}{$R^{2}$} & \multicolumn{2}{|c|}{0.9911} & \multicolumn{2}{|c|}{ Adjusted $R^{2}$} & \multicolumn{2}{|c|}{0.9907} \\
\hline \multicolumn{2}{|c|}{$F(15,364)$} & \multicolumn{2}{|c|}{2493.103} & \multicolumn{2}{|c|}{$\mathrm{P}$-value $(F)$} & \multicolumn{2}{|c|}{0.0000} \\
\hline \multicolumn{2}{|c|}{$\hat{\rho}$} & \multicolumn{2}{|c|}{-0.0605} & $\mathrm{D}-\mathrm{W} \mathrm{s}$ & atistic & 2.1 & \\
\hline
\end{tabular}
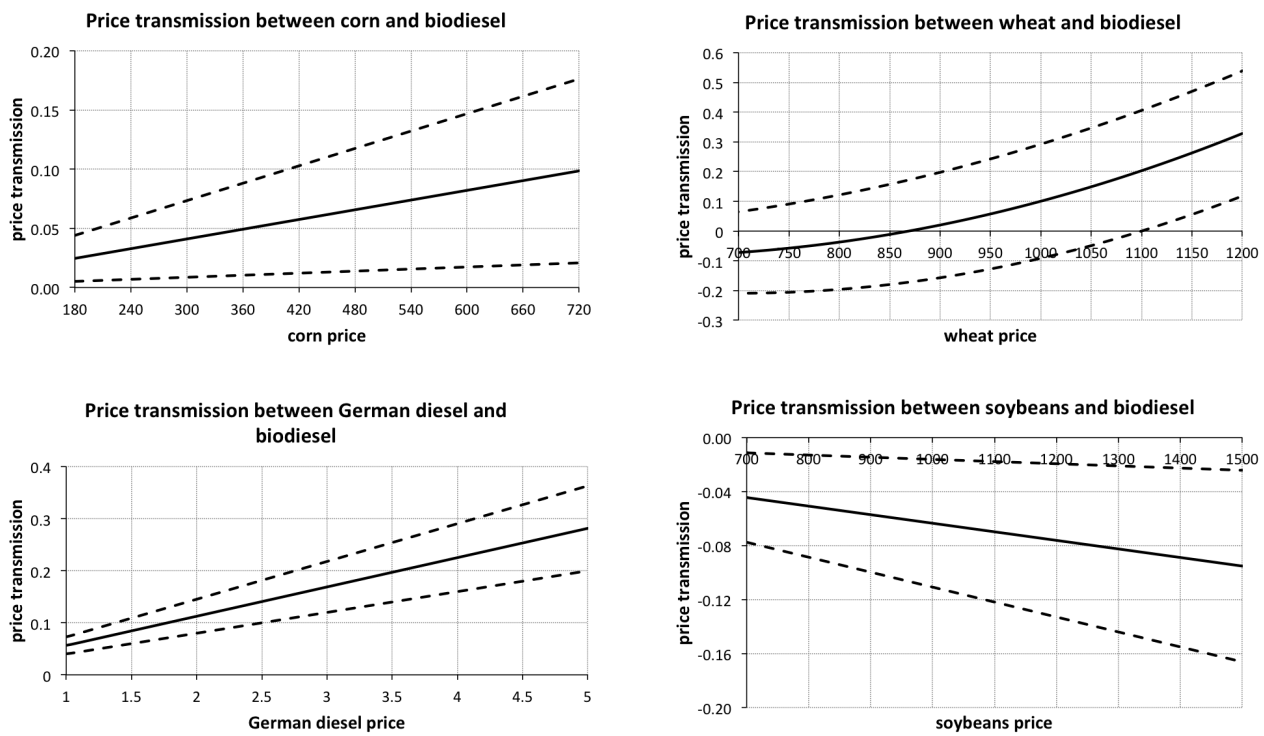

Figure 4: Price-dependent Mutual Responsiveness Between Biodiesel and Corn, Wheat, Soybeans and German Diesel 
With use of Eq. 2, we are able to construct the time-dependent price transmission controlling for the effects of other variables, time trends, seasonality, autocorrelation and endogenity in the biofuel network. The results for the pairs with statistically and economically significant price transmission effects are summarized in Fig. 5.
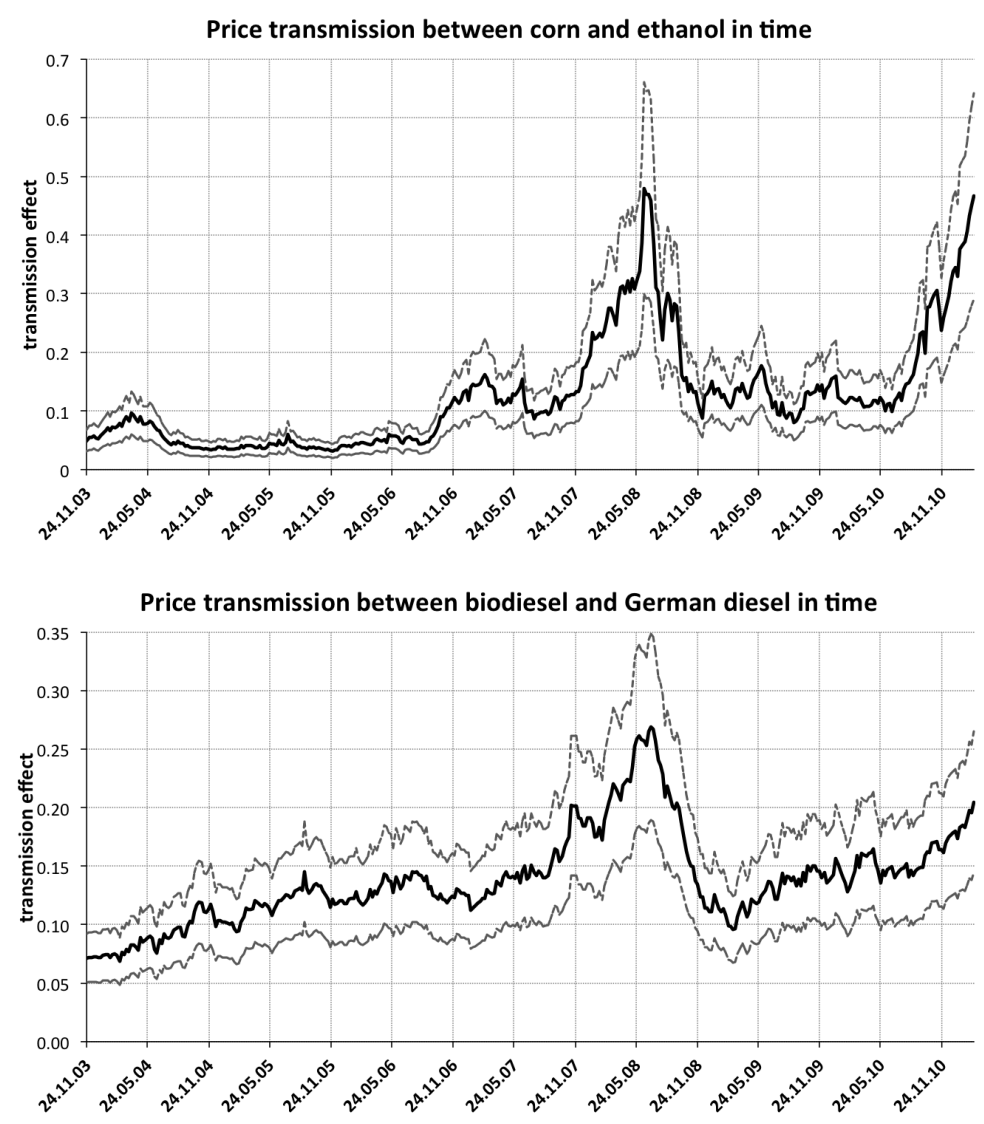

Figure 5: Mutual Responsiveness and Its Evolution in Time.

Both pairs (ethanol-corn and biodiesel-German diesel) share one main feature the price transmissions both increase remarkably during the food crisis of $2007 / 2008$. The most evident is the situation for corn and ethanol where we observe a very low price transmission effect, which is very close to zero, between 2003 and the end of 2007 followed by a rapid increase up to values around 0.5 in the middle of 2008 and dropping to near zero elasticity from 2009 till the middle of 2010 . The price transmission between biodiesel and German diesel reaches lower values than the previous case. Nevertheless, the dynamics shows interesting behavior as well. The values of the price transmission between biodiesel and German diesel start around 0.1 and grow slowly from the end of 2003 till the first half of 2007. From the second 
half of 2007, the transmission rockets upwards and reaches its peak in the middle of 2008 with values around 0.3. Similar to the previous pair, it falls back to relatively low values by the end of 2008. Afterwards, the price transmission begins another, rather slow, growing trend.

\subsection{Causality}

For analyzing causality between a pair of commodities with the previously defined Granger-type test, we need covariance stationary series. Such stationarity requires a constant mean, variance, and autocorrelation structure. We test these assumptions with standard ADF and KPSS tests. Moreover, we test for conditional heteroskedasticity (varying variance) with the help of $\operatorname{GARCH}(1,1)$ and $\mathrm{ARCH}(4)$ models. Note that conditional heteroskedasticity tests are usually omitted in the literature, which raises serious questions because without stable variance we can hardly talk about stable autocorrelation structure and VAR models, which are the basis for Grangertype tests, cannot be correctly estimated. Recall that ADF and ADF-GLS tests have a null hypothesis of a unit-root series, KPSS has a stationarity null, $\operatorname{GARCH}(1,1)$ test has a null of no $\operatorname{GARCH}(1,1)$ effect in the series and similarly, $\mathrm{ARCH}(4)$ has a null of no ARCH effect up to the fourth order (a trading month in our case). We take into consideration only those commodities which have been found to be statistically and economically significant in the previous subsection analyzing the price transmission. The results for the tests for detrended and deseasonalized series, and detrended, deseasonalized and $\operatorname{GARCH}(1,1)$-filtered series are summarized in Tables 5 and 6, respectively. For the detrended and deseasonalized series, we reject a unit-root in all the series (ADF and ADF-GLS), we do not reject a basic form of stationarity (KPSS) but we discover very strong conditional heteroskedasticity of the series (both (G)ARCH tests). Therefore, we need to control for heteroskedasticity to meet the stationarity assumption. To do so, we construct $\operatorname{GARCH}(1,1)$-filtered series, i.e. we estimate $\operatorname{GARCH}(1,1)$ for the specific series, obtain a conditional variance, and then standardize the original series with a square root of the conditional 
variance. The same set of tests shows that the filtered series pass standard ADF, ADF-GLS and KPSS tests as well as tests for additional heteroskedasticity in the series (the filtered series for US gasoline cannot be tested for additional GARCH effect because the covariance matrix is not positive definite: the ARCH test works as needed). Therefore, we can use these $\mathrm{GARCH}(1,1)$-filtered series for causality tests.

Table 5: Stationarity and Heteroskedasticity Tests for Detrended and Deseasonalized Series of Logarithmic Prices. (Note: * , ** and ${ }^{* * *}$ stand for a rejection of the null hypothesis at 10\%, 5\% and 1\% level of significance. The null hypotheses are: "a unit root series" for ADF and ADF-GLS, "stationary series" for KPSS, "no GARCH(1,1) effect" for GARCH(1,1) and "no ARCH effect up to fourth lag" for $A R C H(4))$

\begin{tabular}{c|c|c|c|c|c}
\hline \hline Series & ADF & ADF-GLS & KPSS & GARCH(1,1) & ARCH(4) \\
\hline Ethanol & $-4.4399^{* * *}$ & $-4.4390^{* * *}$ & 0.0653 & $273.507^{* * *}$ & $280.686^{* * *}$ \\
Corn & $-3.6789^{* * *}$ & $-3.4756^{* * *}$ & 0.1356 & $274.804^{* * *}$ & $276.25^{* * *}$ \\
\hline Biodiesel & $-4.5714^{* * *}$ & $-4.3329^{* * *}$ & 0.0961 & $138.633^{* * *}$ & $172.339^{* * *}$ \\
German diesel & $-5.1016^{* * *}$ & $-4.2765^{* * *}$ & 0.1077 & $146.890^{* * *}$ & $217.673^{* * *}$ \\
\hline \hline
\end{tabular}

The results of causality tests are summarized in Table 7. Apart from the previously defined Granger-type causality test, we also test whether the aggregate effect, i.e. the sum of coefficients, is significantly different from zero. To discriminate between immediate effects and delayed effects, we run both tests on lags of 4 (a month) and 12 (a quarter) weeks.

Table 6: Stationarity and Heteroskedasticity Tests for Detrended, Deseasonalized and GARCH(1,1)-filtered Series of Logarithmic Prices. (Notation holds from Table 5)

\begin{tabular}{c|c|c|c|c|c|}
\hline \hline Series & ADF & ADF-GLS & KPSS & GARCH(1,1) & ARCH(4) \\
\hline Ethanol & $-5.6715^{* * *}$ & $-5.6600^{* * *}$ & 0.1673 & 0.7909 & 5.5910 \\
Corn & $-5.6367^{* * *}$ & $-4.9886^{* * *}$ & 0.1550 & 0.1825 & 3.8210 \\
\hline Biodiesel & $6.2520^{* * *}$ & $-6.0822^{* * *}$ & 0.0881 & 1.6671 & 0.9331 \\
German diesel & $-6.4116^{* * *}$ & $-5.2689^{* * *}$ & 0.1008 & 0.3055 & 0.5193 \\
\hline \hline
\end{tabular}

For ethanol, we find that corn Granger-causes ethanol in both the short and medium term. Moreover, the effect is positive. This implies that the increased price of corn increases the price of ethanol in a relatively short time, but the effect 
vanishes quite quickly (the aggregate effect is insignificant after 12 weeks). For biodiesel, we find that German diesel very strongly Granger-causes biodiesel with a positive effect in both the short and medium term. Therefore, we find that production factors influence their products, and not vice versa. To check for potential price dependence in causality, we also apply an augmented version of Eq. 4 where we add an impulse variable also dependent on price - a product of detrended, deseasonalized and $\operatorname{GARCH}(1,1)$-filtered series and a price of relevant commodity. The final product is again GARCH(1,1)-filtered to obtain stationary series. This way, we can distinguish between constant and price-dependent parts of the causal relationship. The results for Granger-type causality tests with 4 lags are summarized in Table 8. We observe that the previously found relationships are confirmed.

Table 7: Causality Tests for Ethanol and Biodiesel. (Note: ${ }^{*},{ }^{* *}$ and ${ }^{* * *}$ stand for a rejection of the null hypothesis "for $X \rightarrow Y, X$ does not Granger-cause $Y$ " and "zero aggregate effect", respectively for $F$ and t-statistics, at $10 \%, 5 \%$ and $1 \%$ level of significance, respectively)

\begin{tabular}{c|cc|cc}
\hline \hline $\begin{array}{c}\text { Impulse } \\
\rightarrow\end{array}$ & $\begin{array}{c}F \text {-statistic } \\
\text { (causality) } \\
\text { 4 weeks }\end{array}$ & $\begin{array}{c}t \text {-statistic } \\
\text { (agg. effect) } \\
\text { 4 weeks }\end{array}$ & $\begin{array}{c}F \text {-statistic } \\
\text { (causality) } \\
\text { 12 weeks }\end{array}$ & $\begin{array}{c}t \text {-statistic } \\
\text { (agg. effect) } \\
\text { 12 weeks }\end{array}$ \\
\hline$C \rightarrow E$ & $4.8799^{* * *}$ & $1.8546^{*}$ & $2.8420^{* * *}$ & 0.9935 \\
$E \rightarrow C$ & 1.4785 & -1.3667 & 1.2452 & -1.3413 \\
\hline \hline$G D \rightarrow B D$ & $9.3019^{* * *}$ & $4.6701^{* * *}$ & $6.1185^{* * *}$ & $3.1075^{* * *}$ \\
$B D \rightarrow G D$ & 0.9343 & -0.9276 & 1.0157 & -0.9901 \\
\hline
\end{tabular}

Table 8: Causality Tests with Price-Level Effect for Ethanol and Biodiesel. (Note: ${ }^{*},{ }^{* *}$ and ${ }^{* * *}$ stand for a rejection of the null hypothesis "for $X \rightarrow Y, X$ does not Granger-cause $Y$ " for $F$ and t-statistics, at 10\%, 5\% and $1 \%$ level of significance, respectively)

\begin{tabular}{c|c|c|c}
\hline \hline $\begin{array}{c}\text { Impulse } \\
\rightarrow\end{array}$ & $\begin{array}{c}F \text {-statistic } \\
\text { (constant } \\
\text { effect) }\end{array}$ & $\begin{array}{c}\text { F-statistic } \\
\text { (price-level } \\
\text { effect) }\end{array}$ & $\begin{array}{c}F \text {-statistic } \\
\text { (joint } \\
\text { effect) }\end{array}$ \\
\hline$C \rightarrow E$ & 1.1055 & 0.495778 & $2.8607^{* * *}$ \\
$E \rightarrow C$ & 0.5823 & 0.6349 & 1.2092 \\
\hline \hline$G D \rightarrow B D$ & $2.6442^{* *}$ & $3.4600^{* * *}$ & $7.6316^{* * *}$ \\
$B D \rightarrow G D$ & 0.4818 & 0.5846 & 1.0482 \\
\hline
\end{tabular}




\section{Conclusions}

The main focus of the paper was twofold: to analyze potential price and time dependence in price transmission (cross-price elasticities) between series, and to examine causal relationships in the biofuel system. We found that ethanol prices are elastic with respect to corn and the effect is price dependent. For biodiesel, the only significant price transmission effect was found with German diesel, which is again price dependent. When converting the price dependence into time dependence, we showed that the food crisis of $2007 / 2008$ had a huge effect on the price transmission levels - for both significant pairs (ethanol-corn and biodiesel-German diesel), the transmission increased markedly - starting at the beginning of 2008, reaching its peak in the middle of the year and returning back to pre-crisis values at the end of the same year. The food crisis thus had an enormous, yet short-lived, effect on elasticities between biofuels and related commodities. These results are quite robust compared to previous studies as we take time trends, seasonality, autocorrelation and endogenity of the series into consideration.

The causality tests uncovered that ethanol is positively affected by corn. For consumer biodiesel, we find that it is very strongly influenced by German diesel prices. The results are supported even when the price effect is taken into consideration.

In this paper, we investigated the linkages between the prices of fuels and related commodities not only as a mechanism to quantitatively understand these markets per se, but also to provide a different way of looking at price transmission. A price transmission analysis (for example GARCH) that is based on assuming complex multivariate relationships with many lags provides good insight on some aspects, for example the time pattern of the impacts of certain shocks, but at the same time it may conceal other important knowledge. For instance a shock on the price of ethanol in Brazil may differ considerably from a the shock on the ethanol price in the US, and there may be a stronger link between biodiesel and fossil fuel prices in Germany that is greater than one would expect if considering fossil fuels and 
biofuels generically.

Our price-dependent causality framework may be applied to understand linkages between fuel and commodity prices around the world, since the question of understanding the relationship of fuel and food prices between various developing countries, China, the West, etc. is one of the key aspects of food and energy security issues. Our analysis also emphasizes that the price transmission between commodities and causal relationship will change over time. While our approach of concentrating on price linkages is much easier to understand and interpret than the complex linkages between quantities, especially because of data reliability, the more detailed biofuel price analysis at the level of all biofuels important countries will help us to understand how food and fuel security are linked through biofuel prices at the global level.

\section{References}

Bollerslev, T. (1986). Generalized autoregressive conditional heteroskedasticity. Journal of Econometrics 31: 307-327.

Carter, C. A., Rausser, G. C. and Smith, A. (2012). The effect of U.S. ethanol mandate on corn prices, presentation at Fifth Berkeley Bioeconomy Conference.

Cha, K. and Bae, J. (2011). Dynamic impacts of high oil prices on the bioethanol and feedstock markets. Energy Policy 39: 753-760.

Chen, X., Huang, H. and Khanna, M. (2012). Land use and greenhouse gas implications of biofuels: Role of technology and policy, SSRN paper.

Chen, X., Huang, H., Khanna, M. and Onal, H. (2011). Meeting the Mandate for Biofuels: Implications for Land Use, Food and Fuel Prices. Working Paper 16697, NBER.

Ciaian, P. and Kancs, D. (2011a). Food, energy and environment: Is bioenergy the missing link? Food Policy 36: 571-580. 
Ciaian, P. and Kancs, D. (2011b). Interdependencies in the energy-bioenergy-food price systems: A cointegration analysis. Resource and Energy Economics 33: $326-348$.

Cochrane, D. and Orcutt, G. H. (1949). Application of Least Squares Regression to Relationships Containing Auto-Correlated Error Terms. Journal of the American Statistical Association 44(225): 32-61.

Dahl, C. A. (2012). Measuring global gasoline and diesel price and income elasticities. Energy Policy 41: 2-13.

Dickey, D. and Fuller, W. (1979). Distribution of the estimators for autoregressive time series with a unit root. Journal of the American Statistical Association 74: $427-431$.

Du, X., Yu, C. L. and Hayes, D. J. (2011). Speculation and volatility spillover in the crude oil and agricultural commodity markets: A Bayesian analysis. Energy Economics 33(3): 497-503.

Elliot, G., Rosenberg, T. and Stock, J. (1996). Efficient tests for an autoregressive unit root. Econometrica 64(4): 813-836.

Granger, C. (1969). Investigating causal relations by econometric models and crossspectral methods. Econometrica 37(3): 424-438.

Hausman, J. (1978). Specification tests in econometrics. Econometrica 46(6): 12511271.

Janda, K., Kristoufek, L. and Zilberman, D. (2012). Biofuels: Policies and impacts. Agricultural Economics 58: 367-371.

Khanna, M., Ando, A. W. and Taheripour, F. (2008). Welfare effects and unintended consequences of ethanol subsidies. Review of Agricultural Economics 30: 411-421. 
Khanna, M., Crago, C. L. and Black, M. (2011). Can biofuels be a solution to climate change? The implication of land use change related emissions for policy. Interface Focus: The Royal Society Journal 1: 233-247.

Kristoufek, L., Janda, K. and Zilberman, D. (2012a). Correlations between biofuels and related commodities before and during the food crisis: A taxonomy perspective. Energy Economics 34: 1380-1391.

Kristoufek, L., Janda, K. and Zilberman, D. (2012b). Mutual Responsiveness of Biofuels, Fuels and Food Prices. Working paper, Centre for Applied Macroeconomic Analysis, Australian National University.

Kwiatkowski, D., Phillips, P., Schmidt, P. and Shin, Y. (1992). Testing the null of stationarity against alternative of a unit root: How sure are we that the economic time series have a unit root? Journal of Econometrics 54: 159-178.

Langholtz, M., Graham, R., Eaton, L., Perlack, R., Hellwinkel, C. and De La Torre Ugarte, D. (2012). Price projections of feedstocks for biofuels and biopower in the U.S. Energy Policy 2012: 484-493.

Luchansky, M. and Monks, J. (2009). Supply and demand elasticities in the U.S. ethanol fuel market. Energy Economics 31: 403-410.

McPhail, L. L. (2011). Assessing the impact of US ethanol on fossil fuel markets: A structural VAR approach. Energy Economics 33: 1177-1185.

Meyer, S., Binfield, J. and Westhoff, P. (2012). Technology adoption under US biofuel policies: Do producers, consumers or taxpayers benefit? European Review of Agricultural Economics 39: 115-136.

Nazlioglu, S. (2011). World oil and agricultural commodity prices: Evidence from nonlinear causality. Energy Policy 39: 2935-2943.

Nazlioglu, S. and Soytas, U. (2011). World oil prices and agricultural commodity prices: Evidence from an emerging market. Energy Economics 33: 488-496. 
Nazlioglu, S. and Soytas, U. (2012). Oil price, agricultural commodity prices, and the dollar: A panel cointegration and causality analysis. Energy Economics 34: $1098-1104$.

Pokrivcak, J. and Rajcaniova, M. (2011). Crude oil price variability and its impact on ethanol prices. Agricultural Economics - Czech 57: 394-403.

Prais, S. and Winsten, C. (1954). Trend estimators and serial correlation. Cowles Commision Discussion Paper: Statistics 308: 1-27.

Rajagopal, D. and Zilberman, D. (2007). Review of environmental, economic and policy aspects of biofuels. Policy Research Working Paper 4341, The World Bank.

Rajcaniova, M., Drabik, D. and Ciaian, P. (2011). International interlinkages of biofuel prices: The role of biofuel policies, presentation at AAEA Meeting, Pittsburgh.

Serra, T. and Zilberman, D. (2012). Biofuel-related price transmission literature: A review, unpublished manuscript.

Serra, T., Zilberman, D., M.Gil, J. and Goodwin, B. K. (2010). Price transmission in the US ethanol market. In Handbook of Bioenergy Economics and Policy (Editors: Khanna, M., J. Scheffran and D. Zilberman), Natural Resource Management and Policy. Springer, 55-72.

Serra, T., Zilberman, D., M.Gil, J. and Goodwin, B. K. (2011). Nonlinearities in the U.S. corn-ethanol-oil-gasoline price system. Agricultural Economics 42: 35-45.

Thompson, W., Meyer, S. and Westhoff, P. (2009). How does petroleum price and corn yield volatility affect ethanol markets with and without an ethanol use mandate? Energy Policy 37: 745-749.

Timilsina, G., Mevel, S. and Shrestha, A. (2011). Oil price, biofuels and food supply. Energy Policy 39: 8098-8105. 
Wooldridge, J. (2009). Introductory econometrics: A modern approach, $4^{\text {th }}$ edition. Cengage Learning.

Zhang, Z., Lohr, L., Escalante, C. and Wetzstein, M. (2009). Ethanol, corn, and soybean price relations in a volatile vehicle-fuels market. Energies 2: 320-339.

Zhang, Z., Lohr, L., Escalante, C. and Wetzstein, M. (2010). Food versus fuel: What do prices tell us. Energy Policy 38: 445-451.

Zilberman, D., Hochman, G., Rajagopal, D., Sexton, S. and Timilsina, G. (2012). The impact of biofuels on commodity food prices: Assessment of findings. American Journal of Agricultural Economics : Forthcoming. 


\section{Working Paper Series}

ISSN 1211-3298

Registration No. (Ministry of Culture): E 19443

Individual researchers, as well as the on-line and printed versions of the CERGE-EI Working Papers (including their dissemination) were supported from institutional support RVO 67985998 from Economics Institute of the ASCR, v. v. i.

Specific research support and/or other grants the researchers/publications benefited from are acknowledged at the beginning of the Paper.

(c) Ladislav Kristoufek, Karel Janda, and David Zilberman, 2013

All rights reserved. No part of this publication may be reproduced, stored in a retrieval system or transmitted in any form or by any means, electronic, mechanical or photocopying, recording, or otherwise without the prior permission of the publisher.

Published by

Charles University in Prague, Center for Economic Research and Graduate Education (CERGE) and

Economics Institute ASCR, v. v. i. (EI)

CERGE-El, Politických vězňu 7, 11121 Prague 1, tel.: +420 224005 153, Czech Republic.

Printed by CERGE-EI, Prague

Subscription: CERGE-EI homepage: http://www.cerge-ei.cz

Phone: + 420224005153

Email: office@cerge-ei.cz

Web: http://www.cerge-ei.cz

Editor: Michal Kejak

The paper is available online at http://www.cerge-ei.cz/publications/working_papers/.

ISBN 978-80-7343-285-0 (Univerzita Karlova. Centrum pro ekonomický výzkum a doktorské studium)

ISBN 978-80-7344-277-4 (Národohospodářský ústav AV ČR, v. v. i.) 
CERGE-EI

P.O.BOX 882

Politických vězňů 7

11121 Praha 1

Czech Republic http://www.cerge-ei.cz 